\section{Received on}

May 18, 2014

Approved on

December 01, 2015

\section{Francisco Liébana- \\ Cabanillas}

Ph.D. In Business Sciences

University of Granada

(Spain)

[franlieb@ugr.es]

\section{Francisco Muñoz-Leiva} Ph.D. in Business Sciences

University of Granada

(Spain)

[franml@ugr.es]

\section{Juan Sánchez-Fernández} Ph.D. in Business Sciences University of Granada (Spain) [sanchezf@ugr.es]

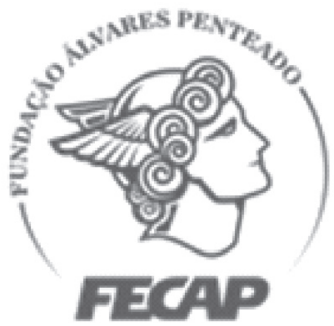

Review of Business Management

\section{Influence of age in the adoption of new mobile payment systems}

\author{
Francisco Liébana-Cabanillas, \\ Francisco Muñoz-Leiva and \\ Juan Sánchez-Fernández \\ Marketing and Market Research, University \\ of Granada, Granada, Spain.
}

Responsible editor: Guilherme de Farias Shiraishi, Dr.

Evaluation process: Double Blind Review

\begin{abstract}
Objective - The aim of this study is to propose and prove a theoretical integrative model which allows determining the relative importance of a new mobile payment system as well as the analysis of possible moderator effects of the age of its potential users within new electronic environments.
\end{abstract}

Design/methodology/approach - To carry out this research, a web experiment based on a general population sample was conducted, in order to analyze the proposed model of behavior towards a new mobile payment system.

Findings - Empirical results demonstrate that the suggested behavior pattern has an adequate adjustment showing that the age of users causes significant differences in the proposed connections between subjective rules and the facility of use and confidence, and again this last one in regard to the facility of use and the attitude toward that use.

Practical implications - The conclusions and implications for management provide alternatives to consolidate this new business opportunity under the new technological developments.

Originality/value - This paper is a pioneer study about the acceptance of mobile payment systems.

Keywords - Mobile payment, acceptance, age, consumer behavior. 


\section{INTRODUCTION: ELECTRONIC COMMERCE AND MOBILE COMMERCE}

The advances in Information and Communication Technologies (ICT), as well as the developments attained in the field of smart phones and the proliferation of the access to the Internet, have favored the increase of the individuals accessibility, which in turn impacted productivity, competitiveness, economic growth, and profitability of the companies' economies, and consequently, of the national economies of some countries (Cotec, 2011).

The use of Internet is more or less intensive according to the industry and the size of the company, but there are certain industries such as finances, tourism, and communication media where the presence of Internet is very important with clear opportunities of generation of value. In those industries, the Internet is regarded as a revolutionary tool that favors the change and the way of doing business. Currently, $44 \%$ of Spanish Internet users between 16 and 55 years say they usually purchase online, and the driver for the purchase is the price, which is implied from the results of the I annual Study on e-Commerce in Spain, elaborated by Elogia (2013).

The evolution of the electronic commerce B2C in Spain in the past years led to a growth in absolute terms from 10,917 million Euros in 2011 to 12,383 in 2012, which represents an annual increase of $13.4 \%$, lower than the $19.8 \%$ of the previous year, and lower to $17.4 \%$ in 2010 (Observatory of Telecommunications and the Information Society - Observatorio de las Telecomunicaciones y la Sociedad de la Información [ONTSI], 2013). Therefore, the growing trend of the electronic commerce $\mathrm{B} 2 \mathrm{C}$ in Spain is maintained, with a slight slowdown in this last year as the result of the international economic instability.

Kalakota and Whinston (2001) have identified four reasons for the electronic commerce having evolved until attaining the current levels: The increase in volume of low amount transactions has obliged many companies to start this kind of activity to reduce costs, 2) The existing competitiveness increases the interest of companies to provide the consumer with better services, 3) Consumers themselves are feeding the competitiveness by demanding more and better services, and 4) The technological advances have favored the increase of transactions with more facility and lower cost to consumers instead of the traditional selling channel.

Despite this, Ruiz (2009) and LiébanaCabanillas (2012) consider that the current situation is still evolving, since both the activities and their nature are changing from a mono-channel perspective to a multi-channel perspective, where therefore the interconnection formula expand, as well as the sale to the final client, with highlight to the use of the mobile phone because of its special connection conditions, as well as because of the possibility to perform commercial transactions. It is therefore evidenced the relation between the electronic commerce and the mobile commerce, the later being considered as part of the first, only being different because of the commercial activity application channel that favors the online sale under a broadly extended support (San-Martín Gutiérrez \& Carpio, 2012).

On the other hand, according to the International Telecommunication Union (ITU) (2013), the total number of mobile subscriptions reached 7,000 million at the end $\mathrm{f} 2012$, which implies a global penetration of $95 \%$ (128\% in developed countries, and $89 \%$ in developing countries). Actually, the Spanish mobile phone market has 55.9 million mobile lines against 19.3 million fixed telephone lines according to the Annual Report of the Telecommunications Market Commission (Comisión del Mercado de Telecomunicaciones, CMT) (2012). In light of such data, we can say that the mobile phone has become an indispensable tool for the everyday life of companies and individuals, with a high level of integration among consumers (Lopez-Catalán \& San-Martín Gutiérrez, 2013).

The mobile commerce has been strictly defined as the exchange or the purchase and 
sale of products, services, or information over the Internet, using mobile phones (Lee, $\mathrm{Hu}, \&$ Yeh, 2003), and broadly defined as the set of all the activities related to commercial transactions performed through the communication networks that are interconnected with wireless devices (Islam, Khan, Ramayah, \& Hossain, 2011), which favors the integration of channels that was mentioned before.

\section{THE MOBILE PAYMENT AS EVOLUTION OF THE TRADITIONAL PAYMENT SYSTEMS}

The payment systems implemented in commercial activities have changed in the past few years with the recently introduced technologies. Consumers are increasingly using telephones to purchase. According to the recent study on Mobile Life ofTNS (Carrión 2012) performed in 58 countries, $15 \%$ of Spanish users have recently used their mobile phones to purchase or to search for information prior to the purchase, although this is still much lower than the traditional payment systems.

According to the $\mathrm{B} 2 \mathrm{C}$ electronic commerce Report of ONTSI (2013) in Spain the payment with bank card $(62.9 \%)$ is the main system of online payment. However, the incidence of this payment method is being reduced in detriment of the exclusively electronic payment platforms, used by $14.9 \%$ of purchasers, and that is the second in the rank. The payment against reimbursement and the pre-paid card $(11.3 \%$ and $7.2 \%$, respectively) have also been used more by Internet users. Although this distribution in the used payment system is very different according to the reference country, many researchers regard the mobile payment as one of the applications with higher potential in this industry, being regarded as the killer application of the mobile phone system.
The mobile payment will basically consist of the performance of payments and transactions between the parties in a fast, comfortable, safe, and simple way at any time, and from any place by means of a mobile terminal. This payment system has different advantages for companies and users over other alternative payment systems in electronic commerce (TPV). For companies and traders: high versatility considering the high number of existing mobile phones, fast transactions, higher comfort and time saving, possibilities of client segmentation customizing the provision of products and services, lower cost (more reduced discount rates), etc. On the other hand, for users it implies more security in the interactions derived from economic transactions thanks to GSM, UMTS, and the SIM card technology of the phone, which allows higher encryption of data handled in transactions, thus improving the reliability, waiting times in the establishments, and reducing the number of errors (San Martín Gutiérrez \& Lopez, 2010), among other advantages. In this regard the mobile payment can be defined as any activity of particular or business nature in which there is the intervention of an electronic support that allows the connection to a mobile network to successfully perform an economic transaction.

As mentioned before, the mobile payment system is a recent innovation in the growth stage broadly extended within the society, and thus it is necessary to review the advantages and bottlenecks of such innovation to the users. The more relevant advantages and bottlenecks of the use of this payment system (advantages in regard to the user and of the system itself) are summarized in Table 1.

In light of the aforementioned, our investigation work is focused on modeling the consumer's behavior when using the SMS mobile payment, as well as the effect of the user's age in determining the intention to use. 
TABLE 1 - Advantages and inconveniences of the mobile payment

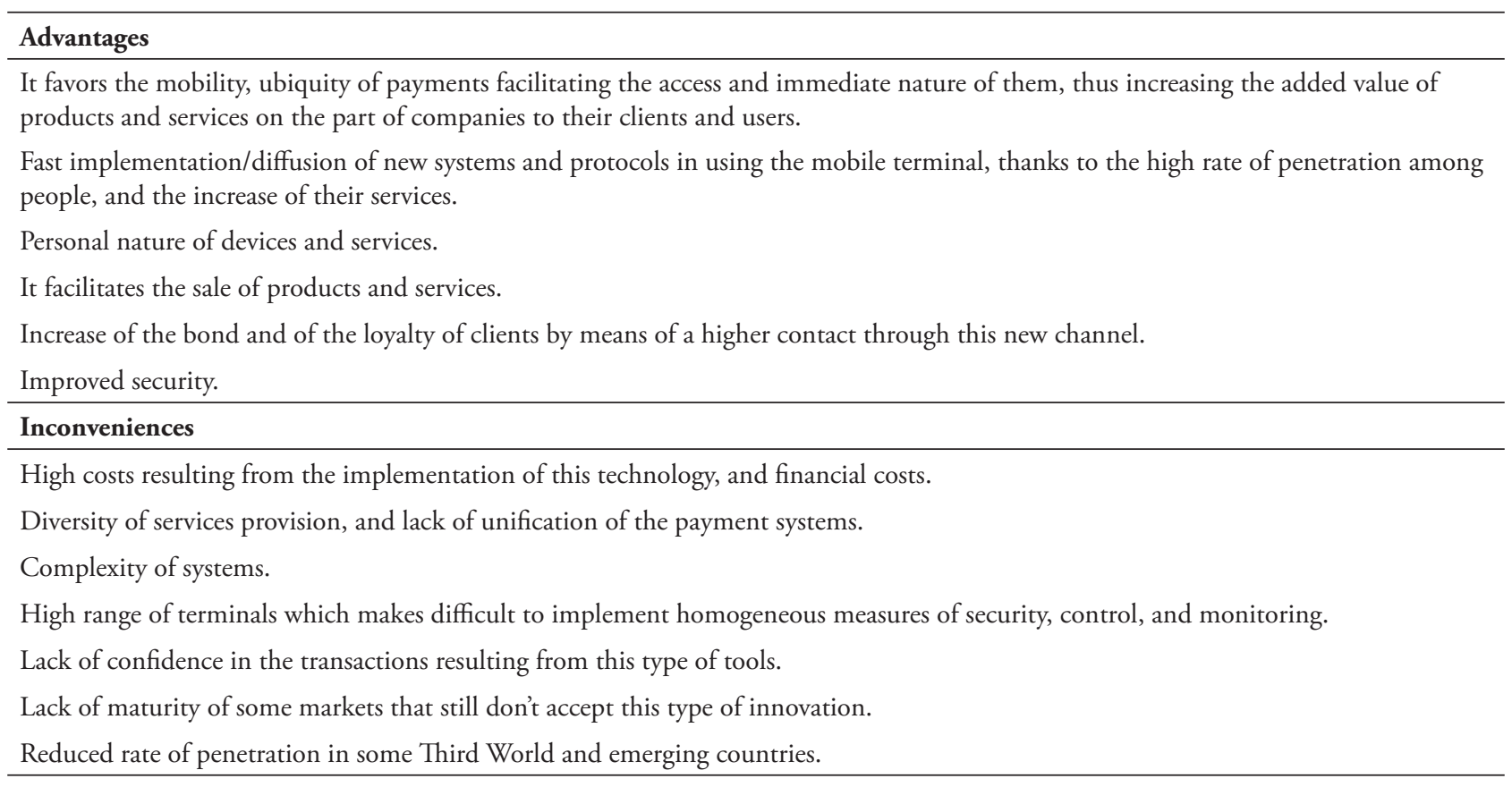

\section{BACKGROUND OF THE INTENTION TO USE THE MOBILE PAYMENT}

There are multiple behavioral decision theories and intention models that the scientific literature has developed to analyze the behavior of individuals before an innovation, most of which are based on studies on social psychology (Pavlou, 2002). From the viewpoint of the consumer's behavior on the Internet, the literature review done in this work is focused on those models and theories that have gotten a major support in the specific literature of marketing and Information Technology. According to a recent meta analysis performed by Wei, Xinyan, and Yue (2011) on the review of literature about the consumer's behavior in adopting mobile commercial services, most of the compared studies has precisely used the Technology Acceptance Model (TAM) (Davis, Bagozzi, \& Warshaw, 1989) to explain such adoption, and from that we have made the following questions: Are the results of the proposed model similar to the previous ones? Does the age affect the adoption of mobile payment systems? Can we identify some implications for the companies of the industry?

The variables we have introduced in the analysis, as well as their meaning and relation regarding the intention, are gathered in Figure 1. 


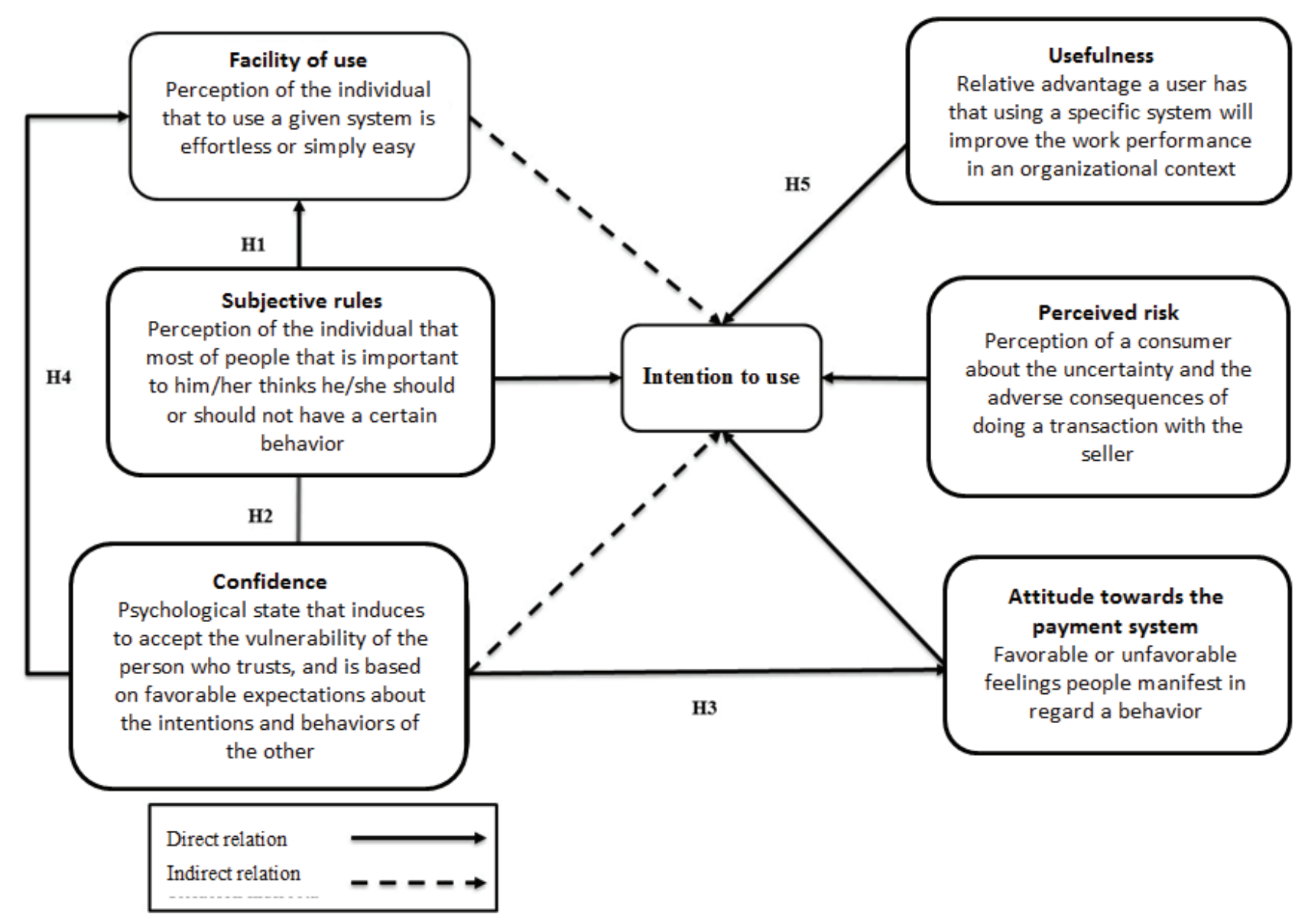

FIGURE 1 - Variables of the model

\section{THE MODERATOR EFFECT OF AGE}

To attain the objectives of the investigation, we propose the inclusion of the study of the age variable, with the background analyzed in the scientific literature from the review of the main classical models. The age of the client/user has an important effect in his/her behavior, thus we will check in our investigation about the adoption of a new payment tool on the Internet if age is also determinant.

Since the first investigations that have studied the impact of Internet on the society, the different authors were capable of defining a common argument line in defense of the moderation of such variable. In this regard, some studies have identified a positive relation between consumers' age and the probability of purchasing products online (Stafford, Turan, \&
Raisinghani, 2004), and on the other hand, others have obtained negative results (Joines, Scherer, \& Scheufele, 2003), or simply no relation at all (Dabholkar, Michelle Bobbitt, \& Lee, 2003). From our point of view, such divergences might be due to several factors such as the sample selection criteria, the moment of the study elaboration, etc.

Several studies have tried to determine whether age can be considered a factor influencing the attitude and behavior of consumers, analyzing aspects such as auto-scanning, and automatic charging, and online services, Internet use, technologies in self-service, technologies in the retail commerce, instant messaging, and mobile commerce, among others.

Regarding the theoretical proposal of the previous model, in this study we explore the role of the user's age with payment tools from the TAM model, and the proposed extensions, including the 
constructs of realized risk and confidence, under the name MPTAM (Mobile Payments Technology Acceptance Model).

Firstly, we refer to the moderator effect of the user's age on the relation between the subjective rules and the facility of use. We started from the idea that those younger users, more prone to accept new technological tools, will perceive a higher facility of use. This statement has been statistically compared to the primary data of surveys on the electronic commerce use, mobile Internet (Accenture, 2011). Therefore, older people will require a bigger implication in the service, and will be more affected by the external influences of the electronic surrounding (Watering, 2005), causing the subjective rule on the facility of use to be higher for those older users (Chung, Park, Wang, Fulk, \& McLaughlin, 2010). On the other hand, the confidence in the contacts of the online media makes more credible and reliable the information offered in the network itself, against possible sources of third party information, which suggests that younger users, for having more experience in this type of surroundings, will show a stronger relation between subjective rules and confidence. For these reasons, the following hypotheses are proposed:

H1: The effect of subjective rules on the facility in using the system is significantly higher among those older users.

H2: The effect of subjective rules on the confidence in the proposed payment system is significantly higher among those younger users.

On the other hand, it is expected that those younger users guided by a bigger knowledge and access to the technological tools (Accenture, 2011; National Institute of Statistics [Instituto Nacional de Estadística, INE], 2013) will have more confidence and facility of use compared to those older ones that will be more reluctant in regard to the new payment tool [significant differences in the previously mentioned studies].
In this regard, the younger users will manifest more willingness to use new technologies, resulting for more confidence in regard to the smaller effort needed to examine the details of the web service itself, as well as to appraise its quality, thus improving the perceived facility of use and attitude (Liébana-Cabanillas, 2012). In view of such circumstances, the following investigation hypotheses are proposed:

H3: The effect of confidence in the facility of use of the proposed payment system is significantly higher among those younger users.

H4: The effect of the perceived confidence of the proposed payment system on the attitude in regard to it is significantly stronger among those younger users.

At last, the younger users will grant a higher importance to the extrinsic reward (equivalent to the perceived usefulness), and will have less difficulty to process complex stimuli, which will determine more intention to use the new payment system (Venkatesh, Morris, Davis, \& Davis, 2003). Furthermore, those older users will be more influenced by the opinion of others. For these reasons we propose the following hypothesis:

H5: The effect of the perceived usefulness of the proposed payment system on the intention is higher to younger users.

The investigation hypotheses are summarized in Table 2 :

TABLE 2 - Summary of hypotheses

\begin{tabular}{ll}
\hline Hypothesis & Relation \\
\hline $\mathrm{H} 1$ & Subjective rules à Facility of use \\
$\mathrm{H} 2$ & Subjective rules à Confidence \\
$\mathrm{H} 3$ & Confidence àFacility of use \\
$\mathrm{H} 4$ & Confidence àAttitude \\
$\mathrm{H} 5$ & Usefulness àIntention to use \\
\hline
\end{tabular}




\section{METHODOLOGICAL ASPECTS}

\section{I Study scope and information collection}

Our investigation has used a national panel of Internet users from which the user visualized a video with the explanation of the new proposed payment system. The used payment system is called Zong, which allows to purchase multiple physical and virtual contents using a mobile terminal through a very simple procedure that allows paying the purchase in different formats (Internet, social networks, TV, and also the point of sale itself). Such payment can be transferred to the telephone bill of the user or to a bank card listed at the moment of the service activation.

The final sample size was 2,012 Internet users coming from a panel of surfers, sampled by convenience and reaching a sampling error of $2.2 \%$ in the estimation of a proportion. The technical information is summarized in Table 3, and the profile of the sample in Table 4.

TABLE 3 - Technical information and characteristics of the sample

\begin{tabular}{|c|c|}
\hline \multicolumn{2}{|c|}{ Under the assumptions of simple random sample } \\
\hline Population & Internet Users \\
\hline Size of population & $14,372,260$ \\
\hline Type of sample & Sample by convenience (not statistical), from a panel of Toluna Spain surfers \\
\hline Incentive to the participation & Through the company itself. \\
\hline Type of survey & Through the Web. \\
\hline $\begin{array}{l}\text { Size of the sample } \\
\text { (started questionnaires) }\end{array}$ & 2,587 \\
\hline Valid sample & 2,012 \\
\hline Sampling error* & $2.2 \%$ \\
\hline $\begin{array}{l}\text { Period of conduction of the field } \\
\text { work }\end{array}$ & January and February of 2012 \\
\hline
\end{tabular}

Note. ${ }^{*}$ In the estimation of a proportion, supposing $\mathrm{p}=\mathrm{q}=0.5$, the confidence level of $95 \%$ and simple random sample.

TABLE 4 - Profile of the analyzed sample

\begin{tabular}{lccc}
\hline Variable & Category & n & Percentage \\
\hline \multirow{2}{*}{ Gender } & Man & 948 & $47.12 \%$ \\
& Woman & 1,064 & $52.88 \%$ \\
& Under 18 years & 1 & $0.05 \%$ \\
& $18-24$ & 192 & $9.54 \%$ \\
& $25-34$ & 642 & $31.91 \%$ \\
Age & $35-44$ & 689 & $34.24 \%$ \\
& $45-54$ & 382 & $18.99 \%$ \\
& $55-64$ & 89 & $4.42 \%$ \\
& Over 65 years & 17 & $0.84 \%$ \\
Education background & W/o education & 22 & $1.09 \%$ \\
& Primary education & 110 & $5.47 \%$ \\
systems & Secondary education & 556 & $27.63 \%$ \\
& University students & 998 & $49.60 \%$ \\
& Graduate students & 316 & $15.71 \%$ \\
& NS/NC & 10 & $0.50 \%$ \\
& Yes & 234 & $11.63 \%$ \\
\end{tabular}

\subsection{Measurement scales}


The questionnaire used to obtain data gathers the adaptation of some of the most recognized scales. To validate such scales, a first quantitative nature test was conducted with bank professionals with minimum experience of ten years in the industry to ensure the validity of the terms used, and a second pilot test was conducted with a sample of students from the Economic and Business Sciences School.

The data analysis was developed in two stages. Firstly, the scales validity was analyzed, then the multi group analysis was performed to verify the proposed associations in a theoretical manner, both described in the following epigraph.

\section{RESULTS}

\section{I Reliability and validity of the proposed scales}

To evidence the suitability of the measurement scales used, different analyses of reliability and validity of the exploratory type (to which the SPSS 15.0 program was used), and of the confirmatory type (AMOS 18 software) were used, and are described in Table 5.
Firstly, to measure the reliability of the scales, the indicator alpha of Cronbach was used, considering the reference value 0.6 (Malhotra, 2004). Furthermore, to compare the convergent and divergent validity of the scales, a Confirmatory Factorial Analysis (CFA) was performed.

The convergent validity was evaluated through the factorial loads of the indicators. It was evidenced that the coefficients were significantly different from zero, and in addition to this that the loads between latent and observed variables were high in all the cases $(\alpha>0.7)$. Therefore, it was possible to confirm that the latent variables properly explained the observed variables.

In regard to the discriminating validity, it was evidenced that the variances were significantly different from zero, and that the correlation between each pair of scales was not above 0.9.

Again, the reliability of the scales was evaluated through a series of indicators extracted from the confirmatory analysis. Precisely, the composed reliability of the construct (CR) and the analysis of the extracted variance (AVE) exceeded the limit used as reference, 0.7 and 0.5 , respectively, as well as other indicators of global adjustment for the measurement model (Barrio García \& Luque Martínez, 2012). 
TABLE 5 - Reliability and validity of the proposed scales

\begin{tabular}{|c|c|c|c|c|c|}
\hline Variable & Item & $\begin{array}{l}\text { Standard coeff. } \\
\text { (t value) }\end{array}$ & $\alpha$ of Cronbach & $\begin{array}{l}\text { Composed } \\
\text { reliability }\end{array}$ & $\begin{array}{c}\text { Extracted } \\
\text { variance }\end{array}$ \\
\hline \multirow{4}{*}{$\begin{array}{l}\text { Subjective } \\
\text { rules }\end{array}$} & NS1 & 0.87 & \multirow{4}{*}{0.93} & \multirow{4}{*}{0.93} & \multirow{4}{*}{0.77} \\
\hline & NS2 & $0.90(57.73)$ & & & \\
\hline & NS3 & $0.84(49.49)$ & & & \\
\hline & NS4 & $0.89(56.88)$ & & & \\
\hline \multirow{5}{*}{ Facility of use } & FU1 & 0.74 & \multirow{5}{*}{0.91} & \multirow{5}{*}{0.92} & \multirow{5}{*}{0.7} \\
\hline & FU2 & $0.90(43.38)$ & & & \\
\hline & FU3 & $0.71(37.88)$ & & & \\
\hline & FU4 & $0.95(45.63)$ & & & \\
\hline & FU5 & $0.92(44.27)$ & & & \\
\hline \multirow{4}{*}{ Usefulness perceived } & UT1 & 0.89 & \multirow{4}{*}{0.95} & \multirow{4}{*}{0.93} & \multirow{4}{*}{0.81} \\
\hline & UT2 & $0.93(68.17)$ & & & \\
\hline & UT3 & $0.86(56.63)$ & & & \\
\hline & UT4 & $0.92(66.21)$ & & & \\
\hline \multirow{4}{*}{ Attitude } & ACT1 & 0.88 & \multirow{4}{*}{0.95} & \multirow{4}{*}{0.95} & \multirow{4}{*}{0.84} \\
\hline & ACT2 & $0.92(64.31)$ & & & \\
\hline & ACT3 & $0.92(64.37)$ & & & \\
\hline & ACT4 & $0.93(65.87)$ & & & \\
\hline \multirow{3}{*}{ Intention to use } & IU1 & 0.94 & \multirow{3}{*}{0.97} & \multirow{3}{*}{0.97} & \multirow{3}{*}{0.92} \\
\hline & IU2 & $0.97(103.70)$ & & & \\
\hline & IU3 & $0.96(101.13)$ & & & \\
\hline \multirow{5}{*}{ Confidence } & CON1 & $0.88(69.73)$ & \multirow{5}{*}{0.97} & \multirow{5}{*}{0.97} & \multirow{5}{*}{0.89} \\
\hline & CON2 & $0.95(91.84)$ & & & \\
\hline & $\mathrm{CON} 3$ & $0.96(96.47)$ & & & \\
\hline & CON4 & $0.95(93.42)$ & & & \\
\hline & CON5 & 0.93 & & & \\
\hline \multirow{4}{*}{ Perceived risk } & RP1 & 0.76 & \multirow{4}{*}{0.92} & \multirow{4}{*}{0.93} & \multirow{4}{*}{0.76} \\
\hline & $\mathrm{RP} 2$ & $0.86(42.45)$ & & & \\
\hline & $\mathrm{RP} 3$ & $0.95(46.97)$ & & & \\
\hline & RP4 & $0.89(43.68)$ & & & \\
\hline
\end{tabular}

The sample was divided into two groups based on the median of the users age distribution. In relation to the values of the sample related to asymmetry and kurtosis, many of them showed problems in a way or another, and thus it was concluded that the sample did not follow a multi variant normal distribution (Mardia Coefficient $_{<=35 \text { years }}=400.705$, critical ratio $\mathrm{CR}-_{<=35 \text { years }}=136.535$; Mardia $_{>35 \text { years }}=502.131$, $\left.\mathrm{CR}_{>35 \text { years }}=203.133\right)$. In this regard, and following the recommendations of Barrio García and Luque Martínez (2012), the estimation method regarded as the most proper was the Method of Maximum Likelihood with the re sampling technique or bootstrapping (with 5000 replicas). The selection of the method was also based on the recommendations of Finney and DiStefano (2006), since we had continuous data, the asymmetry deviations and kurtosis were above many of the variables at 2 and 7, respectively, and the sample size was relatively large. In this re sampling technique, the corrected p-value of Bollen-Stine and the correction of standard errors of the constructs with a confidence level of $95 \%$ were used. 
The adjustment of the multi group model, through absolute, incremental, and parsimony measurements, allowed us to state that the model adjustment was reasonably good $\left(\chi^{2}=4097.508\right.$. $\mathrm{p}=0.00 ; \mathrm{RMSEA}=0.07 ; \mathrm{IFI}=0.95 ; \mathrm{TLI}=0.94$ $\mathrm{CFI}=0.95 ; \mathrm{GFI}=0.87$; $\mathrm{AGFI}=0.85$ ).

Once all the proposed quality measurement scales were evaluated, we checked if all the latent constructs together had a discriminating validity, that is, if the several constructs forming the model were significantly different, since the discriminating validity among the dimensions of the same scale does not ensure the discriminating validity that the different latent constructs should have. An AFC was performed to that end, including all the measurement scales to extract the variance of each of them, as well as the correlations between constructs, and their confidence intervals.
In our case, it was evidenced that the correlations between constructs were not too high, no construct had a confidence interval of 1 , and the correlations between indicators were below the root of the variance extracted from each of the constructs taken two by two, which allowed us to conclude that globally there was a discriminating validity between the different considered latent constructs.

Once verified the goodness of the model adjustment, the final result was graphically put together from the standardized coefficients for the behavior model that measures the use of the new mobile payment system according to the user age (Figure 2).

In addition, the statistical significance of the structural loads of the model was also analyzed (Table 6).

TABLE 6 - Statistical significance of the standardized structural loads

\begin{tabular}{lcccc}
\hline \multirow{2}{*}{$\begin{array}{l}\text { Relations between } \\
\text { constructs }\end{array}$} & \multicolumn{2}{c}{ YOUTHS (Below 35) } & \multicolumn{2}{c}{ ELDER (Over 35) } \\
\cline { 2 - 5 } & Estimated coefficient & p-value & Estimated coefficient & p-value \\
\hline NSà CON & 0.742 & $* * *$ & 0.656 & $* * *$ \\
CONà FU & 0.519 & $* * *$ & 0.371 & $* * *$ \\
NSà FU & 0.079 & 0.102 & 0.258 & $* * *$ \\
FUà UT & 0.564 & $* * *$ & 0.595 & $* * *$ \\
CONà RP & -0.336 & $* * *$ & -0.391 & $* * *$ \\
FUà ACT & 0.251 & $* * *$ & 0.26 & $* * *$ \\
UTà ACT & 0.472 & $* * *$ & 0.565 & $* * *$ \\
RPà ACT & -0.084 & $* * *$ & -0.091 & $* * *$ \\
CONà ACT & 0.253 & $* * *$ & 0.13 & 0.475 \\
ACTà IU & 0.082 & 0.044 & 0.023 & $* * *$ \\
RPàIU & -0.081 & 0.001 & -0.109 & $* * *$ \\
UTàIU & 0.398 & $* * *$ & 0.508 & $* * *$ \\
NSàIU & 0.494 & $* * *$ & 0.454 & $*$ \\
\hline
\end{tabular}

Note. $p$-value ${ }^{* * *}=p$-value $<0.001$

In the model of users with age under 35 years, all the relations manifested showed to be significant, except for the relation between the subjective rules and the facility of use, attaining a percentage of the explanation of the use intention variable of $63.3 \%$. The intention to use in the model of users with age under 35 years maintains a significant positive relation through the subjective rules $(\beta=0.49)$, attitude $(\beta=0.08)$, and perceived usefulness $(\beta=0.40)$, and the risk perceived in the negative direction $(\beta=-0.08)$.

On the other hand, in the extracted model for the users over 35 years all the proposed relations were significant, except for the relation 
between attitude and intention, attaining an explanation of the intention to use of $68.2 \%$. In this case, the intention to use was determined by the subjective rules $(\beta=0.45)$, usefulness $(\beta=0.51)$, and perceived risk $(\beta=-0.11)$. Therefore, in our model the intention to use in the group of younger users is smaller than in the group of older users.

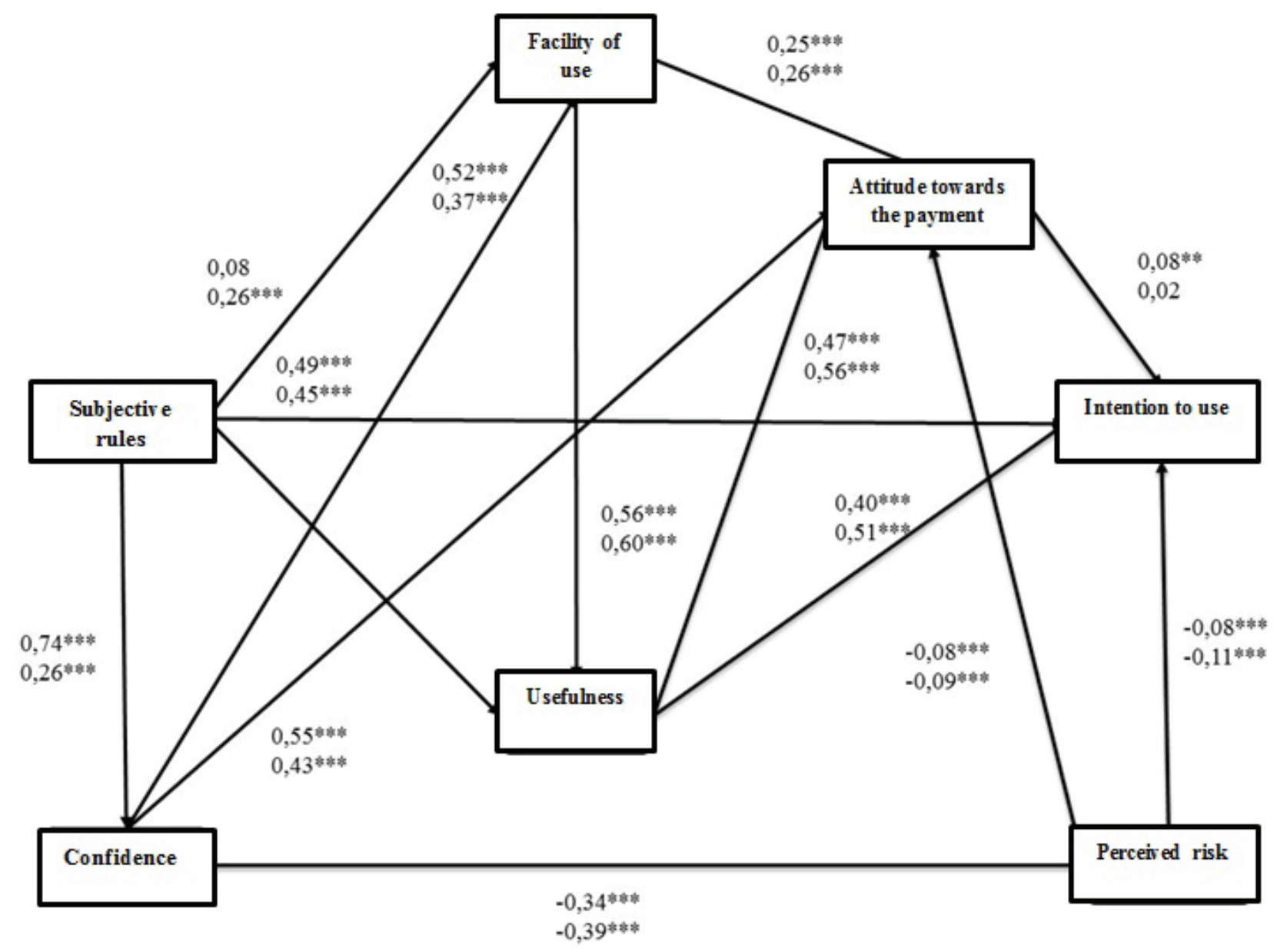

$<35$ years

FIGURE 2 - Results of the multi group model (standardized coefficients). Under 35 / Over 35 years

\section{I Results of the proposed hypotheses}

To evaluate the moderator effect of the user age manifested in the questionnaire, the sample was divided into two groups based on the median of the users age distribution. To that end, the invariance test was carried out through the comparison of the Chi-square $\left(\chi^{2}\right)$ values for the general model and for the restricted model, resulting in significant differences (Table 7 ). 
TABLE 7 - Invariance analysis in the multi group model based on the age of users

\begin{tabular}{lcccccc}
\hline Model & $\chi \mathbf{2}$ & g.1. & $\boldsymbol{\Delta} \chi \mathbf{2}$ & $\mathbf{\Delta}$ g.l. & p-value & Invariance \\
\hline General & 4097.508 & 364 & 587.198 & 364 & 0.000 & No \\
Restricted & 4684.706 & 728 & & & & \\
\hline
\end{tabular}

After evidencing the existence of significant differences, and with the aim of verifying the moderator effect of proposed variables, a test was carried out to evidence the regression coefficients or weights between the structural models, considered two by two, using a modification of the $\mathrm{t}$ of Student test for independent samples (Goodman \& Blum, 1996). The evaluation was carried out by means of the procedure proposed by Chin (2000), through a multi group analysis in function of the $t$ of Student test (through a parametric analysis using the $t$ test with $\mathrm{m}$ $+\mathrm{n} 2$ degrees of freedom) according to the following formulation, where $\mathrm{B}_{\mathrm{i}}$ are the estimated coefficients without standardization, and $\mathrm{SE}_{\mathrm{i}}$ are the standard errors for each coefficient:

$$
\begin{gathered}
H o: B 1=B 2 \\
t=\frac{B_{1}-B_{2}}{\sqrt{S E_{1}^{2}+S E_{2}^{2}}}
\end{gathered}
$$

The results of the structural equations analysis, as well as the results of the hypothesis are shown in Table 8. As observed, the comparison manifested the existence of significant differences in the $\mathrm{H} 1, \mathrm{H} 2, \mathrm{H} 3$, and $\mathrm{H} 4$ hypotheses.

\begin{tabular}{|c|c|c|c|c|c|c|c|c|}
\hline \multirow[b]{2}{*}{ Нyp } & \multirow[b]{2}{*}{ Effect } & \multicolumn{5}{|c|}{ AGE } & \multirow{2}{*}{$\begin{array}{l}\text { Significant } \\
\text { differences? }\end{array}$} & \multirow{2}{*}{$\begin{array}{l}\text { Hypothesis } \\
\text { proved? }\end{array}$} \\
\hline & & Below 35 years & p-value & Above 35 years & p-value & T Test & & \\
\hline 1 & NSàFU & 0.078 & 0.102 & 0.234 & 0.001 & -2.70 & Yes & Yes \\
\hline 2 & NSà CON & 0.756 & 0.001 & 0.668 & 0.001 & 2.10 & Yes & Yes \\
\hline 3 & CONà FU & 0.499 & 0.001 & 0.331 & 0.001 & 2.91 & Yes & Yes \\
\hline 4 & CONà ACT & 0.257 & 0.001 & 0.132 & 0.001 & 2.81 & Yes & Yes \\
\hline 5 & UTàIU & 0.394 & 0.001 & 0.481 & 0.001 & -1.55 & No & Yes \\
\hline
\end{tabular}

TABLE 8 - Results of the proposed hypotheses

\section{CONCLUSIONS AND IMPLICATIONS}

\section{I Conclusions}

After of a review of the current situation of the electronic commerce and mobile commerce, the objective of our investigation was to model the behavior of Internet users in view of a new SMS mobile payment tool, as well as the analysis of the age in accepting such payment system, and the factors determining this.

In regard to the general results, firstly, it was demonstrated that those younger users are more prone to accept new technological tools, while the older ones will need a higher implication of the service, therefore being more influenced by the subjective rules of the users community. This indicates that the older users will have a stronger relation between the subjective rule and the facility of use, and therefore the companies of the industry should pay special attention to get to know the usability of the tool for this group. Secondly, those younger users, for having a higher level of experience in the surrounding, have more confidence in the opinion of the group of reference contacts, opposed to those older 
users who will be more reluctant to improve their level of confidence based on them, and therefore the younger users are more prone to accept new technological tools, while the older users will need a higher implication in the service, being thus more influenced by the subjective rules of the community itself. Thirdly, the younger users maintained a stronger relation between confidence and facility of use than the group of older users. Furthermore, the younger users maintained a more intense relation between confidence in the system and attitude in regard to the use, comparing to the older ones. Finally, it was not demonstrated that the intention to use among younger users improves their intention to use, in regard to the older ones, motivated by the electronic environment where the investigation is performed, and in regard to the higher willingness they generate in regard to it.

Regarding the direct effects, firstly, to those younger users the variable with higher influence on the intention was the subjective rules. This high relation is motivated by the online environment where the user activity is developed, because the network itself is the place where the communication between people occurs, and it is precisely inside the network where the user will form his/her acceptance of the payment tool. As observed, it is precisely this variable that most determines the intention to use, which suggests that it is the very element determining the intention to use a payment system in the virtual environment of younger users. Secondly, the intention to use is determined by the usefulness of the mobile payment system. This second element reinforces the TAM proposals, but it is quantitatively apart from the values of external influences. Thirdly, the attitude manifests a nearly significant relation with the intention to use in the case of the younger user. At last, the perceived risk manifests a negative relation with the intention to use because of the uncertainty that the tool supposes to the new user and/or the possible negative consequences of the purchase act. Precisely, the influence of such effect was broadly verified in multiple fields, and our results corroborate and reinforce the already stated proposal.
In the case of older users, the intention to use is firstly determined by the usefulness of the payment tool itself in the analyzed medium, which reinforces previous investigations. Secondly, for the subjective rules, which demonstrates that older users prefer a more utilitarian view of the tool opposed to a social view of the tool. Thirdly, the perceived risk, corroborating previous investigations that define older users as users with a higher level of risk aversion. Finally, the attitude is not significantly related to intention.

On the other hand, it is empirically evidenced that the client/user age has an important effect on his/her behavior, and on the acceptance of technology. In our experiment, the existence of significant differences between the relations proposed based on the user age was evidenced, actually in the relations between subjective rules and facility of use, subjective rules and confidence, confidence and facility of use, as well as confidence and attitude. Finally, in the relation proposed between usefulness and intention to use, no significant differences were detected based on the age of users.

In regard to the relation between subjective rules and facility of use, it was demonstrated that older users are more prone to use simple and easy tools than younger users, with no doubt motivated by their smaller technological propensity, and higher requirement of the influence from others. On the other hand, in the relation between subjective rules and confidence, we found the inverse situation, where younger users trust more the comments of their contacts in the network. In both relations, the influence of the network conditions the results.

On the other hand, the relation between confidence and facility of use and attitude is more intense amongst younger users, suggested by their higher propensity towards new technologies.

\subsection{Business implications}

Although it is true that payment systems are as old as the humankind itself, the implementation and use of modern payment systems has modified 
the economic and business scenario. Among the most current payment systems, we can highlight the mobile payment because of the importance of wireless devices in the current society, the accessibility supposed by this medium to the users, and the technological improvements continuously developed both in the online world (mainly Internet and social networks) and in the offline world (readers, PoS, etc.).

The results obtained in this investigation propose interesting implications for the diffusion of mobile payment systems through the Internet. In actual terms, the knowledge of the virtual payment acceptance process is very useful to define strategies oriented to the clients of such systems.

In this regard, it is noteworthy the need to realize an effort to make people improve their perception and general opinion about the purchase on the Internet. For this reason, companies should make communication efforts to diffuse the advantages of this type of tools. There are surely elements favoring the companies, directly collaborating with them, which is the high percentage of mobile phone penetration, and the increased access to social networks through the mobile Internet. These trends will allow the access to purchase portals from any place, at any time, overcoming the important advantages of the electronic commerce itself.

Furthermore, and as the result of the context where the investigation was developed, it is observed that Internet surfers are very sensitive to the opinions of their social surrounding regarding their purchase behavior on the Internet, and even more to the social networks themselves. Precisely because of this social influence and or the number of users taking part of the networks, companies need to position themselves among their clients, and the acquaintances and friends of their clients, to stimulate as much as possible their sales and the payment of such sales by enabling agile and efficient payment systems.

Although the intention to use in our case is very influenced by external influences as opposed to attitude, it is important to pay attention to the user surrounding, because the user behavior will depend on such surrounding, and in concrete terms the eWOM should be favored, since it will influence the behavior and will improve the intention to use the new tool.

More concretely, due to the segments resulting from the application of the moderator effect of age among users, companies will be in condition to define strategies adapted to the influence patterns, elaborating differentiated value proposals (segmented marketing), which properly satisfy clients and improve their loyalty, and consequently collaborate in attaining the objectives of the companies themselves. In this regard, the organizations that decide to enter a new market should differentiate the arguments or proposals on which their advertisement or promotion messages are based. Particularly, if the action is intended to younger users, the arguments should not be based on the usefulness and simplicity of the new payment system, but should focus on security and/or privacy concerns, as a way to improve the confidence, and therefore the attitude towards the service. On the other hand, and based on the importance of external influences to the groups of surfers, the already mentioned eWOM should be a more interesting tool for those older users less prone to technology and more prone to the influence of others.

\section{NOTE OF THE AUTHOR}

This study is financed with the financial support provided by the project of Investigation and Excellence P10-SEJ-6768 of the Economy and Science Council of the Andalucía Regional Government (Consejería de Economía y Ciencia de la Junta de Andalucía).

\section{REFERENCES}

Accenture (2011). Retos y oportunidades del universo digital móvil en España: Más ubicuo, más social, más personal. Recuperado de www.accenture. com/es-es/Pages/insight-retos-oportunidades-universodigital-movil.aspx 
Barrio García, S. del, \& Luque Martínez, T. (2012). Análisis de ecuaciones estructurales. En T. Luque Martínez (Coord.), Técnicas de análisis de datos en investigación de mercados (pp. 489-557). Barcelona: Pirámide.

Bosque Rodríguez, I. A. R., Herrero Crespo, Á., \& Samones Sánchez, M. M. G. (2005). La propensión a innovar en la adopción del comercio electrónico B2C: un análisis sobre la base de la Teoría de Acción Razonada. In Encuentro de Profesores Universitarios de Marketing [Archivo de ordenador] (pp. 723-738). Madrid: Emark.

Carrión, M. (2012). Una visión del consumidor móvil a nivel mundial. Recuperado de http:// recursos.anuncios.com/files/503/13.pdf

Chin, W. W. (2000). Frequently asked questionspartial least squares and PLS-Graph. Recuperado de http://disc-nt.cba.uh.edu/chin/plsfaq.htm

Chung, J. E., Park, N., Wang, H., Fulk, J., \& McLaughlin, M. (2010). Age differences in perceptions of online community participation among non-users: An extension of the Technology Acceptance Model. Computers in Human Behavior, 26(6), 1674-1684.

Comisión del Mercado de las Telecomunicaciones. (2012). Informe trimestral de la comisión del mercado de las telecomunicaciones 2011. Recuperado de www.cmt.es

Cotec (2011). Informe Cotec 2011. Recuperado de www.cotec.es/index.php/pagina/publicaciones/ novedades/show/id/945/titulo/informe-cotec-2011-tecnologia-e-innovacion-en-espana

Dabholkar, P. A., Michelle Bobbitt, L., \& Lee, E. J. (2003). Understanding consumer motivation and behavior related to self-scanning in retailing: Implications for strategy and research on technology-based self-service. International Journal of Service Industry Management, 14(1), 59-95.

Davis, F. D., Bagozzi, R. P., \& Warshaw, P. R. (1989). User acceptance of computer technology: A comparison of two theoretical models. Management Science, 35(8), 982-1003.
Elogia. (2013). I Estudio anual eCommerce IAB Spain. Recuperado de http://www.iabspain.net/ wp-content/uploads/downloads/2013/06/I_estudio_ ecommerce.pdf

Finney, S. J., \& DiStefano, C. (2006). Nonnormal and categorical data in structural equation modeling. En G. R. Hancock \& R. O. Muller (Eds.) Structural equation modeling: A second course (269-314). Connecticut: IAP.

Goodman, J. S., \& Blum, T. C. (1996). Assessing the non-random sampling effects of subject attrition in longitudinal research. Journal of Management, 22(4), 627-652.

Instituto Nacional de Estadística (2013). Encuesta de uso de TIC y Comercio Electrónico en las empresas. Recuperado de www.ine.es

International Telecommunication Union (2013). World Telecommunication/ICT Indicators Database. Recuperado de www.itu.int/en/ITU-D/Statistics/ Pages/stat/default.aspx

Islam, M. A., Khan, M. A., Ramayah, T., \& Hossain, M. M. (2011). The adoption of mobile commerce service among employed mobile phone users in Bangladesh: Self-efficacy as a moderator. International Business Research, 4(2), 80-89.

Joines, J. L., Scherer, C. W., \& Scheufele, D. A. (2003). Exploring motivations for consumer Web use and their implications for e-commerce. Journal of consumer marketing, 20(2), 90-108.

Kalakota, R., \& Robinson, M. (2001). E-business 2.0: Roadmap for success. Indianapolis, IN: Addison-Wesley Professional.

Lee, C. W., Hu, W. C., \& Yeh, J. H. (2003, May). A system model for mobile commerce. En Distributed Computing Systems Workshops, 2003. Proceedings. 23rd International Conference on (pp. 634-639). IEEE.

Liébana-Cabanillas, F. (2012). El papel de los medios de pago en los nuevos entornos electrónicos (Doctoral dissertation). Departamento de 
Comercialización e Investigación de Mercados. Universidad de Granada, Granada, Espanha.

Lopez-Catalán, B., \& San Martín Gutiérrez, S. (2013). Perfiles de compradores españoles por teléfono móvil. Universia Business Review, (38), 50-67.

Malhotra, N. K. (2004). Investigación de Mercados: Un enfoque aplicados. México: Pearson Educación.

McKnight, D. H., Choudhury, V., \& Kacmar, C. (2002). The impact of initial consumer trust on intentions to transact with a web site: a trust building model. The Journal of Strategic Information Systems, 11(3), 297-323.

Observatorio de las Telecomunicaciones y la Sociedad de la Información (2013). Estudio sobre Comercio Electrónico B2C 2012. Recuperado de http://www.ontsi.red.es/ontsi/ es/estudios-informes/estudio-b2c-2012edici\%C3\%B3n-2013

Pavlou, P. A. (2002). A theory of planned behavior perspective to the consumer adoption of electronic commerce. MIS Quarterly, 3O(1), 115-143.

Pikkarainen, T., Pikkarainen, K., Karjaluoto, H., \& Pahnila, S. (2004). Consumer acceptance of online banking: An extension of the technology acceptance model. Internet Research, 14(3), 224-235.

Ruiz, A. (2009). Sistemas y entornos de pago para la adquisición de contenidos y servicios electrónicos en red (Doctoral dissertation). Departamento de Ingeniería de la Información y las Comunicaciones, Universidad de Murcia, Murcia, Espanha.
San Martín Gutiérrez, S., \& Carpio, M. (2012). La venta por teléfono móvil desde el punto de vista de las empresas españolas. Universia Business Review, (34), 124-143.

San Martín Gutiérrez, S., \& López Catalán, B. (2010). Posibilidades de la compraventa B2C por teléfono móvil en comparación con Internet. Cuadernos de Gestión, 10(1), 17-34.

Stafford, T. F., Turan, A., \& Raisinghani, M. S. (2004). International and cross-cultural influences on online shopping behavior. Journal of Global Information Technology Management, 7(2), 70-87.

Taylor, S., \& Todd, P. A. (1995). Understanding information technology usage: A test of competing models. Information Systems Research, 6(2), 144-176.

Venkatesh, V., \& Bala, H. (2008). Technology acceptance model 3 and a research agenda on interventions. Decision Sciences, 39(2), 273-315.

Venkatesh, V., Morris, M. G., Davis, G. B., \& Davis, F. D. (2003). User acceptance of information technology: Toward a unified view. MIS quarterly, 27(3), 425-478.

Watering, M. van (2005). The impact of computer technology on the elderly. Recuperado de http://feeling-younger.eu/wp-content/ uploads/2012/11/HCI_Essay_Marek_van_de_ Watering.pdf

Wei, G., Xinyan, Z., \& Yue, M. (2011). Literature review on consumer adoption behavior of mobile commerce services. E -Business and E -Government (ICEE). International Conference on, 1-5, 6-8 Mayo 2011. 


\section{ANNEX 1: MEASUREMENT SCALES USED}

\begin{tabular}{|c|c|c|}
\hline \multicolumn{3}{|l|}{ Scale of subjective rules } \\
\hline $\begin{array}{l}\text { People whose opinions I value would approve the use of Zong to } \\
\text { purchase a product. }\end{array}$ & \multirow{4}{*}{$\begin{array}{l}\text { Likert of } 7 \text { points } \\
1=\text { Entirely disagree } \\
7 \text { = Entirely agree }\end{array}$} & \multirow{4}{*}{$\begin{array}{l}\text { Taylor and Todd (1995), and } \\
\text { Bosque Rodríguez, Herrero Crespo, } \\
\text { \& Samones Sánchez. (2005) }\end{array}$} \\
\hline $\begin{array}{l}\text { Most of people I take into consideration thinks I should use Zong to } \\
\text { purchase a product. }\end{array}$ & & \\
\hline I am expected to use Zong to purchase a product. & & \\
\hline People close to me would agree I use Zong to purchase a product. & & \\
\hline \multicolumn{3}{|l|}{ Scale of facility of use } \\
\hline The interaction with the tool is clear and understandable. & \multirow{5}{*}{$\begin{array}{l}\text { Likert of } 7 \text { points } \\
1=\text { Entirely disagree } \\
7=\text { Entirely agree }\end{array}$} & \multirow{5}{*}{$\begin{array}{l}\text { Venkatesh and } \\
\text { Bala (2008) }\end{array}$} \\
\hline The interaction with the tool does not require mental effort. & & \\
\hline It seems to me that the tool will easily do what I want it to do. & & \\
\hline $\begin{array}{l}\text { It seems to me a useful tool to make small purchases on the Internet/ } \\
\text { social networks. }\end{array}$ & & \\
\hline In general, the tool is easy to use. & & \\
\hline \multicolumn{3}{|l|}{ Scale of perceived usefulness } \\
\hline $\begin{array}{l}\text { Using Zong can help me doing the purchases I usually do through } \\
\text { the Internet/social networks. }\end{array}$ & \multirow{4}{*}{$\begin{array}{l}\text { Likert of } 7 \text { points } \\
1=\text { Entirely disagree } \\
7 \text { = Entirely agree }\end{array}$} & \multirow{4}{*}{$\begin{array}{l}\text { Pikkarainen, Pikkarainen, Karjaluoto, } \\
\text { \& Pahnila (2004) and Muñoz (2008) }\end{array}$} \\
\hline $\begin{array}{l}\text { Using Zong can increase my efficacy when purchasing on the } \\
\text { Internet/social networks }\end{array}$ & & \\
\hline $\begin{array}{l}\text { Using Zong in my purchases on the Internet/social networks can } \\
\text { increase my productivity. }\end{array}$ & & \\
\hline $\begin{array}{l}\text { In general, Zong can be useful to me when purchasing on the } \\
\text { Internet/social networks. }\end{array}$ & & \\
\hline \multicolumn{3}{|l|}{ Scale of attitude of use } \\
\hline I don't like - I like & \multirow{4}{*}{$\begin{array}{l}\text { Semantic differential of } \\
7 \text { points }\end{array}$} & \multirow{4}{*}{$\begin{array}{l}\text { Del Bosque et al. (2005), and Muñoz } \\
(2008)\end{array}$} \\
\hline Absurd - Intelligent & & \\
\hline Boring - Interesting & & \\
\hline Unpleasant - Pleasant & & \\
\hline \multicolumn{3}{|l|}{ Scale of intention to use } \\
\hline $\begin{array}{l}\text { Assuming I had access to the Zong payment system, I intended to use } \\
\text { is to purchase on the Internet/social networks. }\end{array}$ & \multirow{3}{*}{$\begin{array}{l}\text { Likert of } 7 \text { points } \\
1=\text { Entirely disagree } \\
7=\text { Entirely agree }\end{array}$} & \multirow{3}{*}{ Venkatesh and Bala (2008) } \\
\hline $\begin{array}{l}\text { If I had access to Zong over the next few months, I consider I will use } \\
\text { it instead of another alternative system. }\end{array}$ & & \\
\hline $\begin{array}{l}\text { Assuming I had access to the Zong, I would use it over the next few } \\
\text { months. }\end{array}$ & & \\
\hline \multicolumn{3}{|l|}{ Scale of confidence towards the use of virtual payment systems } \\
\hline I believe Zong will keep the promises and commitments it makes. & \multirow{5}{*}{$\begin{array}{l}\text { Likert of } 7 \text { points } \\
1=\text { Entirely disagree } \\
7=\text { Entirely agree }\end{array}$} & \multirow{5}{*}{$\begin{array}{l}\text { Pavlou (2002 [study 1]), and Muñoz } \\
\text { (2008) }\end{array}$} \\
\hline Zong is reliable. & & \\
\hline I would qualify Zong as honest. & & \\
\hline I think Zong is responsible. & & \\
\hline In general, Zong seems of trust to me. & & \\
\hline
\end{tabular}


Other people can get to know information of my online transactions if I use this tool.

There is a high potential for money loss if I purchase on the Internet/ social networks through this tool.

There is a major risk when purchasing on the Internet/social networks using this tool.

I think that purchasing on the Internet/social networks using his tool is a risky choice.
Likert of 7 points

$1=$ Entirely disagree

$7=$ Entirely agree

McKnight, Choudhury, \& Kacmar

(2004b), and Muñoz (2008) 